\title{
Secondary Recovery of Columbite from Tailing Dump in Nigerian Jos Mines Field
}

\author{
${ }^{1}$ Ayeni*, F.A, ${ }^{1}$ Madugu, I. A, ${ }^{1}$ Sukop, P, ${ }^{2}$ Ibitoye, S. A, ${ }^{2}$ Adeleke, A. A, ${ }^{3}$ Abdulwahab, M \\ ${ }^{1}$ National Metallurgical Development Centre (NMDC), P. M. B. 2116, Jos, Nigeria. \\ ${ }^{2}$ Department of Materials Science and Engineering, Obafemi Awolowo University, \\ Ile-Ife, Nigeria \\ ${ }^{3}$ Department of Metallurgical Engineering, Ahmadu Bello University, Zaria, Nigeria \\ *Corresponding Author: ayeflo@yahoo.com
}

\begin{abstract}
Millions of tons of tailing dump at Rayfield mine in Jos in North Central Plateau state of Nigeria have been found to contain large quantity of columbite. Initial attempts to recover columbite concentrates by local miners and mineral speculators from the columbite rich tailing dump failed due to the ineffective processing route employed. Using cone and quartering sampling method, $0.5 \mathrm{~kg}$ of the columbite tailing was obtained for sieve and chemical analyses. $50 \mathrm{~kg}$ of $<1 \mathrm{~mm}$ fraction of the sample was subjected to a first stage magnetic concentration in a three poles Dry High Intensity Magnetic Separator (DHMS) that separated the columbite in the third pole. The re-grind of the $+0.355 \mathrm{~mm}$ rougher concentrate fraction (containing interlocking columbite) to pass the sieve aperture was treated on the DHMS in the second stage. The rougher concentrate undersize and columbite pre-concentrate of the first stage magnetic separation were then gravity concentrated on the air float machine. The Rayfield tailings and final concentrate were assayed using ED-XRFS to obtain $12.5 \%$ and $69.6 \% \mathrm{Nb}_{2} \mathrm{O}_{5}$, respectively. The recovery and separation efficiency were $77.95 \%$ and $77.88 \%$ in that order. The magnetic and gravity concentrations were found effective at $77.95 \%$ recovery for columbite from the Rayfield tailing dump. This study also provided database for optimum recovery of columbite from tailings of mining sites of similar composition.
\end{abstract}

Key Words: Tailing dump, columbite, recovery, concentration, characterization, Magnetic, Gravity, Recovery, Assay, Flowsheet 


\section{INTRODUCTION}

Recent economic and technological changes in mineral processing techniques have enabled old dumped tailings of columbite to become profitable to process again. Columbite contains oxide of niobium $\left(\mathrm{Nb}_{2} \mathrm{O}_{5}\right)$ and oxide of tantalum $\left(\mathrm{Ta}_{2} \mathrm{O}_{5}\right)$ in different proportions. When the niobium oxide is much more than the tantalum oxide, the mineral is called columbite $\left\{(\mathrm{Fe}, \mathrm{Mn}) \mathrm{Nb}_{2} \mathrm{O}_{6}\right\}$, while it is called tantalite $\left\{(\mathrm{Fe}, \mathrm{Mn}) \mathrm{Ta}_{2} \mathrm{O}_{6}\right\}$, when the tantalum oxide content is much higher. Niobium metal is best known in connection with HSLA (High Strength Low Alloy) steels, heat resistance alloys in aerospace, vehicle engines and supersonic air-crafts [1]. Columbite is one of the most important solid minerals traded in the world market. Hence, many miners and processing engineers find one way or the other to acquire mining area rich in this mineral. Millions of tons of the tailings of columbites and cassiterites mined at the Rayfield minesfield by the British Miners in the late sixties were still very rich in the mineral [2]. In the past, when mining and processing of columbite and cassiterite were done at this mines field, less attention was given to the tailings either because their uses were not well defined then or there was no appropriate method of beneficiating them.

Columbite is the main important mineral form of niobium. The columbite ore dressing usually involves pre-concentrate and concentrate clean-up. In order to recover columbite, a flowsheet which combines magnetic with gravity processing has been found suitable [3]. The choice of any part of or the entire processing route would depend on the nature of the ore, particularly the content of $\mathrm{Nb}_{2} \mathrm{O}_{5}$ and $\mathrm{Ta}_{2} \mathrm{O}_{5}$ in the ore relative to its associated minerals and impurities and difference in their physical properties. The concentration processes may be carried out by wet or dry gravity, magnetic or electrostatic methods to produce concentrates containing up to $70 \%$ combined pentoxide $\left(\mathrm{Nb}_{2} \mathrm{O}_{5}\right.$ and $\left.\mathrm{Ta}_{2} \mathrm{O}_{5}\right)$ to meet extraction requirements. However, the universally employed method for the concentration of columbite ores are magnetic and gravity [4]. Solid minerals are so important in the production of materials for different engineering applications, that today's mineral processing engineering encourages the optimum method of beneficiating tailings for maximum secondary recovery, leaving little or no values in the final tailings.

The aim of this study is to characterize and assay the columbite tailings of the Rayfield mine waste, and establish an effective and appropriate secondary recovery processing route for this tailing.

\section{MATERIALS AND METHODS}

\subsection{Materials}


The material used for this study was collected from columbite tailing dump located in Rayfield village, about $15 \mathrm{~km}$ from Jos, Plateau State, Nigeria.

\subsection{Methods}

\subsubsection{Sample collection}

The sample of the Rayfield tailings dump was collected from the site using grab sampling method. Fifty five kilogram $(55 \mathrm{~kg})$ of the columbite tailings was picked randomly within a short period of time as the representative from the tailing dump.

\subsubsection{Sample preparation}

Using cone and quartering method, fifty five kilogram sample $(55 \mathrm{~kg})$ of the tailing was poured into a conical heap, flattened and divided into four identical parts using a metal cutter. Two opposite corners were taken as sample; the other two corners were kept aside. The portion chosen as the sample was further coned and quartered and this continued until a sample of 0.50 $\mathrm{kg}$ of the columbite tailing was obtained for sieve and chemical analyses.

\subsubsection{Particle size distribution analysis}

The columbite tailing was subjected to screen distribution analysis on a set of sieve arranged using geometric progression based on $\sqrt{2}$. The $500 \mathrm{~g}$ prepared sample of the tailing was placed on the topmost screen and the nest of sieve was automatically vibrated for 20 minutes. The weight of ore retained on each sieve was then determined [5].

\subsubsection{Energy dispersion-X Ray fluorescence spectrometry (ED-XRF) analysis}

Twenty grams of the sample was finely ground to pass through a 200-250 mesh sieve. It was dried in a Genlab oven, model MINO/50 and type Y6D144 at $105^{\circ} \mathrm{C}$ for at least 1 hour and cooled. Thereafter, the sample was intimately mixed with a binder in the ratio of 5:1 sample(s) to cellulose flakes binder and pelletized at a pressure of about $19.4 \mathrm{~kg} / \mathrm{m}^{2}$ in a pelletizing machine. At this stage, the pelletized sample(s) were stored in a dessicator for analysis. The machine, EDXRFS, was switched on and allowed to stabilize for 2 hours. It was set at the default mode to analyze the compositions of the Rayfield columbite tailings and products from each processing unit, in form of oxides of the elements present [6]. The results of analysis was reported in percentage $(\%)$.

\subsubsection{Concentration method}


Fifty kilograms of the columbite tailing was screened using the $1 \mathrm{~mm}$ sieve. The oversize portion was fed into rod milling machine to reduce the size and the mill product was recycled to the 1 $\mathrm{mm}$ sieve. The milling was repeated until the $50 \mathrm{~kg}$ lot passed through the sieve. The $50 \mathrm{~kg}$ undersize of $1 \mathrm{~mm}$ was thereafter fed into an optimum efficiency calibrated Dry High-intensity Magnetic Separator (Rapid) Model 4-3-15 OG, operating at a feed rate of $250 \mathrm{~kg} / \mathrm{hr}$ and $0.5,0.2$ and 1.0 A for magnetite, hematite and columbite; respectively. The equipment was switched on and the sample was processed for about 15 minutes. $50 \mathrm{~kg}$ of the Rayfield tailing $(-1.00 \mathrm{~mm})$ was fed through the hopper of the rapid and the shutter was opened slightly to allow even and gradual spread of the feed on the magnetic belt. The magnetic belt conveyed the feed through the three discs of the rapid. The ferromagnetic material (magnetite) in the feed was separated from the feed at the first disc, the second disc separated rougher (hematite, escaped magnetite and some interlocking columbite), the third disc removed columbite and the non-magnets are collected in front of the belt. For maximum recovery, the rougher was processed further by sieving using $0.355 \mathrm{~mm}$ sieve size. The use of this sieve size was based on the results of the sieve analysis which showed that $0.355 \mathrm{~mm}$ size fraction had the highest number of grains reported. The oversize particles of $0.355 \mathrm{~mm}$ was crushed using the rod mill until all passed through the sieve. The undersize was recycled to the Rapid for further separation.

The undersize of the $0.335 \mathrm{~mm}$ sieve was further reprocessed using pneumatic (air) floating table, Kipp Kelly model MY. The products of the air floating table were rougher concentrate, middling, and tailings. The middling was recycled to the table while the tailing made up the final tailing. The pre-concentrate from the rapid which consisted mainly of columbite, small quantity of silica and hematite was further processed using air floating machine operated at a tilted angle of $60^{\circ}$, speed of $2.75 \mathrm{stroke} / \mathrm{s}$. motor speed $1425 \mathrm{rpm}$ and feed rate of $250 \mathrm{~kg} / \mathrm{hr}$. The products of the air flotation were final concentrate (columbite), middling and tailing. The air floatation procedure was repeated for the middling and tailing while the resulting tailing was added to the tailing of the rougher process to form the final tailing of the process. Finally, samples were taken from products of each processing unit for assaying using ED-XRFS machine (Energy Dispersion-X Ray Fluorescence spectrometry) Minipal 4 Model 20.

\section{RESULTS AND DISCUSSION}

\subsection{Results}

The results obtained on the particle size and chemical composition analyses are presented in Tables 1 and 2 respectively, while that of mass and metallurgical balances, recovery and separation efficiency for the process are presented in Tables 3 to 5 . The secondary recovery processing flowsheet and the particle size distributions curve are presented in Figures 1 and 2 respectively. 
Table 1: Grain size distribution of Rayfield columbite tailing

\begin{tabular}{lccccccc}
\hline Sizes $(\mu \mathrm{m})$ & $\begin{array}{c}\text { Weight } \\
(\mathrm{g})\end{array}$ & $\begin{array}{c}\text { Weight } \\
\text { Percentage } \\
(\%)\end{array}$ & $\begin{array}{c}\text { Nominal } \\
\text { aperture } \\
\text { size } \\
(\mu \mathrm{m})\end{array}$ & $\begin{array}{c}\text { Cumulative } \\
\text { weight }(\%) \\
\text { undersize }\end{array}$ & $\begin{array}{c}\text { Cumulative } \\
\text { weight }(\%) \\
\text { oversize }\end{array}$ & $\begin{array}{c}\mathrm{Nb}_{2} \mathrm{O}_{5} \\
\%\end{array}$ & $\begin{array}{l}\% \\
\mathrm{Ta}_{2} \mathrm{O}_{5}\end{array}$ \\
\hline+1000 & 6.04 & 1.2 & 1000 & 98.8 & 1.2 & 0.3 & 0.0 \\
$-1000+850$ & 17.87 & 3.6 & 850 & 95.2 & 4.8 & 2.5 & 0.4 \\
$-850+710$ & 49.79 & 10.0 & 710 & 85.2 & 14.8 & 3.8 & 0.7 \\
$-710+500$ & 75.41 & 15.1 & 500 & 70.1 & 29.9 & 8.2 & 1.1 \\
$-500+355$ & 101.55 & 20.3 & 355 & 49.8 & 50.2 & 11.4 & 1.5 \\
$-355+250$ & 137.47 & 27.5 & 250 & 22.3 & 77.7 & 16.8 & 1.9 \\
$-250+180$ & 78.22 & 15.7 & 180 & 6.6 & 93.4 & 17.2 & 2.1 \\
$-180+125$ & 23.29 & 4.7 & 125 & 1.9 & 98.1 & 16.1 & 2.1 \\
$-125+90$ & 7.46 & 1.5 & 90 & 0.4 & 99.6 & 8.4 & 1.7 \\
-90 & 2.06 & 0.4 & & & & & \\
\hline Total & 499.16 & \multicolumn{7}{c}{} & & & & & & \\
\hline
\end{tabular}

Table 2: Chemical analysis of Rayfield columbite tailing and concentrate using ED - XRF

\begin{tabular}{llllll}
\hline $\begin{array}{l}\text { Parameters } \\
\text { (\%) }\end{array}$ & Rayfield tailing & Pre - conc. & Rougher & Concentrate & Tailing \\
\hline $\mathrm{Al}_{2} \mathrm{O}_{3}$ & 4.70 & 1.30 & 0.22 & 0.43 & 4.84 \\
$\mathrm{SiO}_{2}$ & 40.3 & 7.00 & 9.30 & 4.51 & 54.60 \\
$\mathrm{TiO}_{2}$ & 0.74 & 0.90 & 0.14 & 0.56 & 0.54 \\
$\mathrm{Fe}_{2} \mathrm{O}_{3}$ & 12.90 & 12.36 & 1.17 & 11.18 & 3.48 \\
$\mathrm{ZrO}_{2}$ & 7.80 & 1.31 & 76.26 & 1.13 & 18.90 \\
$\mathrm{Nb}_{2} \mathrm{O}_{5}$ & 12.50 & 63.50 & 2.16 & 69.60 & 2.91 \\
$\mathrm{Ag}_{2} \mathrm{O}$ & 1.90 & $\mathrm{ND}$ & $\mathrm{ND}$ & $\mathrm{ND}$ & 0.62 \\
$\mathrm{Ta}_{2} \mathrm{O}_{5}$ & 1.90 & 4.59 & 0.22 & 4.88 & 0.31 \\
$\mathrm{ThO}_{2}$ & 2.78 & 0.27 & 0.33 & 0.19 & 1.42 \\
\hline
\end{tabular}

Table 3: Mass balance for the process

\begin{tabular}{cc}
\hline Item & Quantity $(\mathrm{kg})$ \\
\hline Feed & 50 \\
Concentrate & 7 \\
Rougher concentrate & 19 \\
Tailing & 23.7 \\
Loss & 0.3 \\
\hline
\end{tabular}


Table 4: Metallurgical balance for the process

\begin{tabular}{lcccc}
\hline ITEM & $\begin{array}{c}\text { WEIGHT } \\
(\mathrm{Kg})\end{array}$ & $\begin{array}{c}\mathrm{ASSAY} \\
\mathrm{Nb}_{2} \mathrm{O}_{5} \\
(\%)\end{array}$ & $\begin{array}{c}\text { WEIGHT } \\
\mathrm{OF} \mathrm{Nb}_{2} \mathrm{O}_{5} \\
\left(\mathrm{Kg}^{2}\right.\end{array}$ & $\begin{array}{c}\text { DISTRIBUTION } \\
\mathrm{OF} \mathrm{Nb}_{2} \mathrm{O}_{5}(\%)\end{array}$ \\
\hline Feed & 50 & 12.5 & 6.25 & 100 \\
Concentrate & 7 & 69.6 & 4.87 & 77.9 \\
Rougher concentrate & 19 & 2.16 & 0.41 & 8.3 \\
Total Concentrate & 26 & 20.7 & 5.28 & 86.2 \\
Unaccounted Loss & - & - & 0.28 & 4.5 \\
Tailing & 23.7 & 2.91 & 0.69 & 11.0 \\
\hline
\end{tabular}

Table 5: Recovery and Separation efficiency for the process

\begin{tabular}{cc}
\hline Item & Percentage (\%) \\
\hline Retrospective recovery & 80.1 \\
Check-in/check-out & 77.95 \\
Recovery & \\
Separation efficiency & 77.88 \\
Grade & 69.9 \\
\hline
\end{tabular}

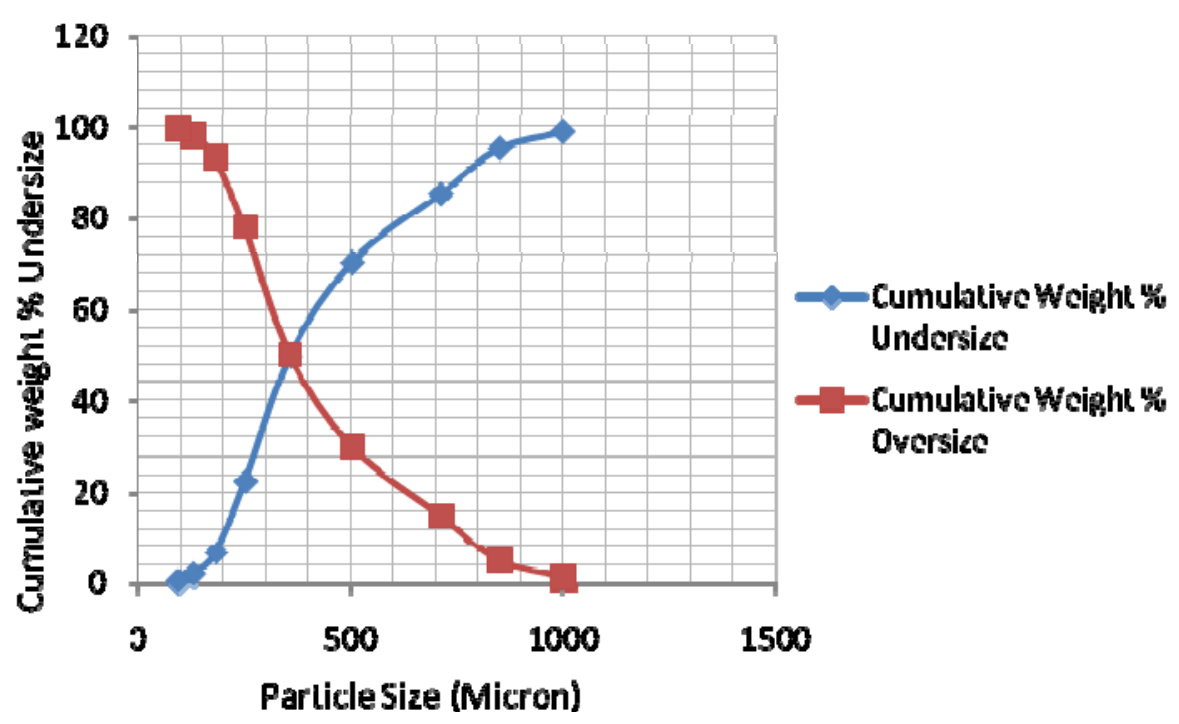

Fig. 1: Particle size distribution curve 


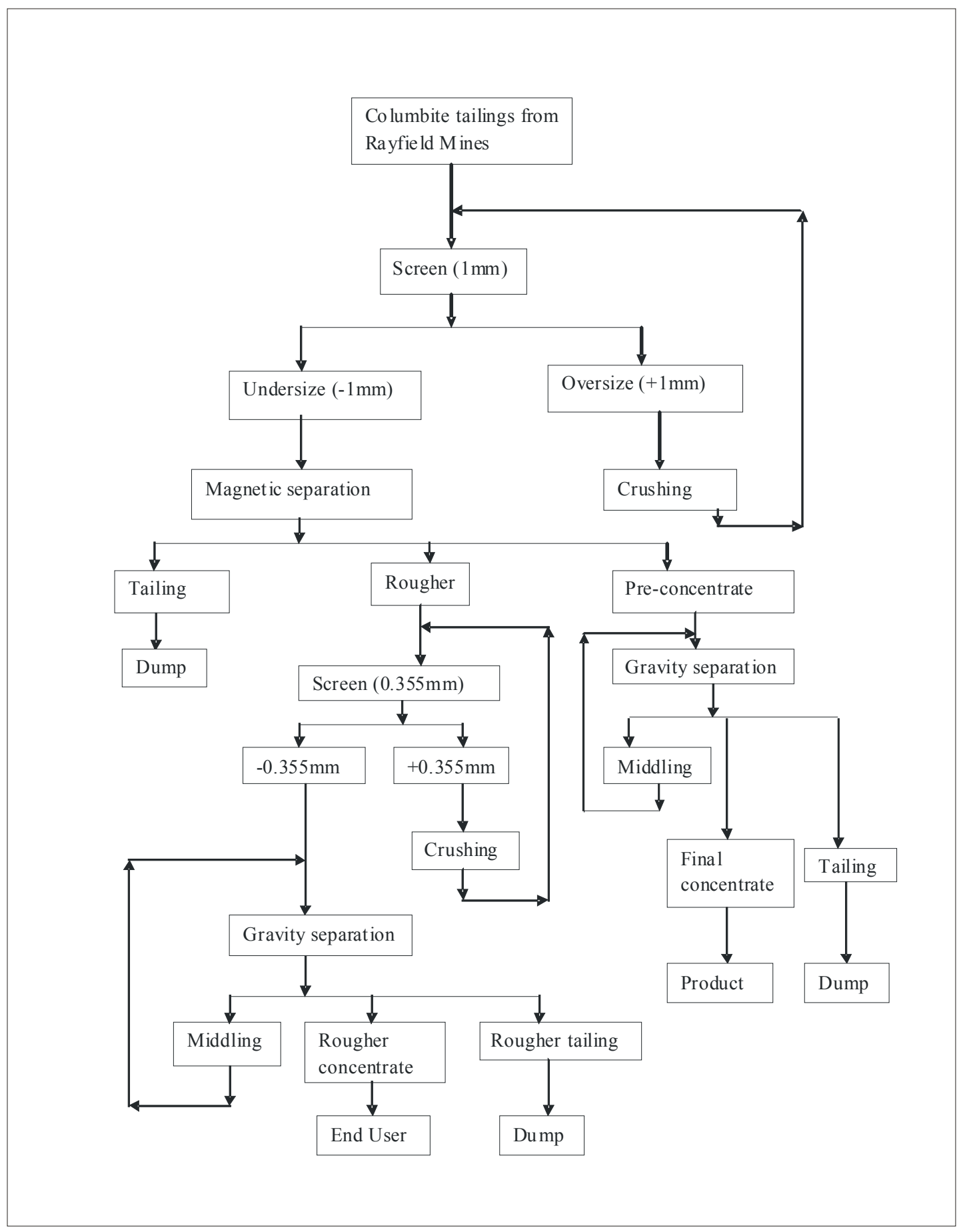

Fig.2: Secondary Recovery Process Flowsheet for Processing of Rayfield Tailing

\subsection{Discussion of Results}

The particle size analysis gave $98.8 \%$ and $49.8 \%$ for fractions of Rayfield columbite tailing passing $1 \mathrm{~mm}$ and $0.355 \mathrm{~mm}$ sieves. The chemical analysis of the $98.8 \%$ cumulative undersize 
fraction gave $12.5 \% \mathrm{Nb}_{2} \mathrm{O}_{5}$. These results indicate that the tailing is rich and can be economically processed at this size fraction assay which is far higher than 4 to $6 \% \mathrm{Nb}_{2} \mathrm{O}_{5}$ required for columbite tailing [7]. The size distribution also indicates that the tailing is alluvial and the form may lead to reduction in energy for comminution and hence cost of processing.

The chemical analysis result of the Rayfield tailing passing $1 \mathrm{~mm}$ shows $40.3 \%$ silica, $12.9 \%$ iron oxide, $7.8 \%$ zirconia and $12.5 \%$ columbite as its major constituents. However, after magnetic separation the pre-concentrate has a significant reduction of silica and zirconia to $7 \%$ and $1.31 \%$ respectively and increase of columbite to $63.5 \%$, while the iron remains almost the same at $12.36 \%$, which may be due to interlocking with the columbite. The result of the cleaning operation of pre-concentrate using pneumatic table indicates the presence of $4.51 \%$ silica, $11.18 \%$ iron oxide, $1.13 \%$ Zirconia and $69.6 \%$ columbite in the final concentrate. These results showed that the columbite content was increased by about $82.04 \%$, while reduction percents of $88.81,13.33$ and 85.51 were obtained for silica, iron oxide and zirconia, respectively. The results suggest that the combined magnetic/gravity concentration method produced a substantial upgrade of the tailings.

The mass and metallurgical balance of the two final products from cleaning of pre - concentrate shows $7 \mathrm{~kg}$ and $77.9 \%$ distribution of columbite in the final concentrate assaying $69.6 \%$ respectively with a loss of $0.3 \mathrm{~kg}$. Combining the final concentrate with the rougher concentrate, mass and metallurgical balance of $26 \mathrm{~kg}$ concentrate, $23.7 \mathrm{~kg}$ final tailing and $86.2 \%$ distribution of columbite assaying $20.7 \%$ respectively were obtained. This indicates that the proportion of metals in the feed that reports to concentrate may have an inverse relationship with the grade [7]. Recovery and separation efficiency of $77.95 \%$ and $77.88 \%$ respectively was obtained using this processing method. The appreciable recovery and separation efficiency achieved with very little loss is an evidence of the effectiveness of the applied processing route for the Rayfield columbite tailing dump.

\section{CONCLUSIONS}

Rayfield tailing has been characterized into particle size and composition using physical and chemical methods respectively. ED-XRF spectrometry analysis indicates that $12.5 \%$ columbite, $40.3 \%$ silica, $7.8 \%$ zirconia, $12.9 \%$ iron, alumina and other associated minerals form the constituents of the tailing. The tailing has been successfully beneficiated to a higher columbite content of $69.6 \%$ and lower silica, zirconia, iron contents of $4.51 \%, 1.13 \%$ and $11.18 \%$ in that order using magnetic and gravity concentration methods. Recovery and separation efficiency using these concentration methods or process route are established to be $77.95 \%$ and $77.88 \%$ respectively. This is an evidence of the effectiveness of the processing route applied for the tailing dump. 


\section{REFERENCES}

[1] Ogbonna, A. I., Nwakaudu S.M., Onyemobi O.O (1999), "Strategic Mineral Deposits in Nigeria (The neglected Case of Niobotantalites)", proceedings of $16^{\text {th }}$ Nigerian Metallurgical Society Annual Conference, Abuja; pp59.

[2] Ayeni, F. A., Alabi, O. O, Ola, S. O (1999), "Beneficiation of Tailings"; Proceedings of $16^{\text {th }}$ Nigeria Metallurgical Society Annual Conference, Abuja; pp67-75.

[3] Zlagnean, M; Sarpong, R.K (2000), "Processing of Valuable Vein Minerals, AS Molybdenite, Monazite, Magnetite, Pyrite and Ilmenite", Proceedings of the XXI International Mineral Processing Congress, Vol. 4, pp C10-5

[4] Schumann, W (1985), "Collins Photo Guide for Rocks, Minerals and Gemstone"; Harper Collins Publisher, Glasgow, pp 12.

[5] Ola, S. A., Usman, G. A., Odunaike, A. A., Kollere, S. M., Ajiboye, P. O., Adeleke, A. O. (2009), "Pilot Scale Froth Flotation Studies To Upgrade Nigerian Itakpe Sinter Grade Iron Ore To A Midrex-Grade Super-Concentrate"; Journal of Minerals \& Materials Characterization \& Engineering, Vol. 8, No. 5, pp 405-416.

[6] MiniPAL 4 Model, (2005), "Energy Dispersive X-Ray Fluorescence Spectrometry (EDXRFS) PANalytical B.V", Lelyeg1, 7602 EA, Almelo, The Netherlands, pp 3-9.

[7] Wills, B. A (1988), "Mineral Processing Technology", $5^{\text {th }}$ Edition; Pergamon Press, Oxford pp 8-45.

[8] Gupta, C. K (2003), Chemical Metallurgy Principles and Practice; Willey - Verlag GmbH \& Co. KGaA, Weinheim. 